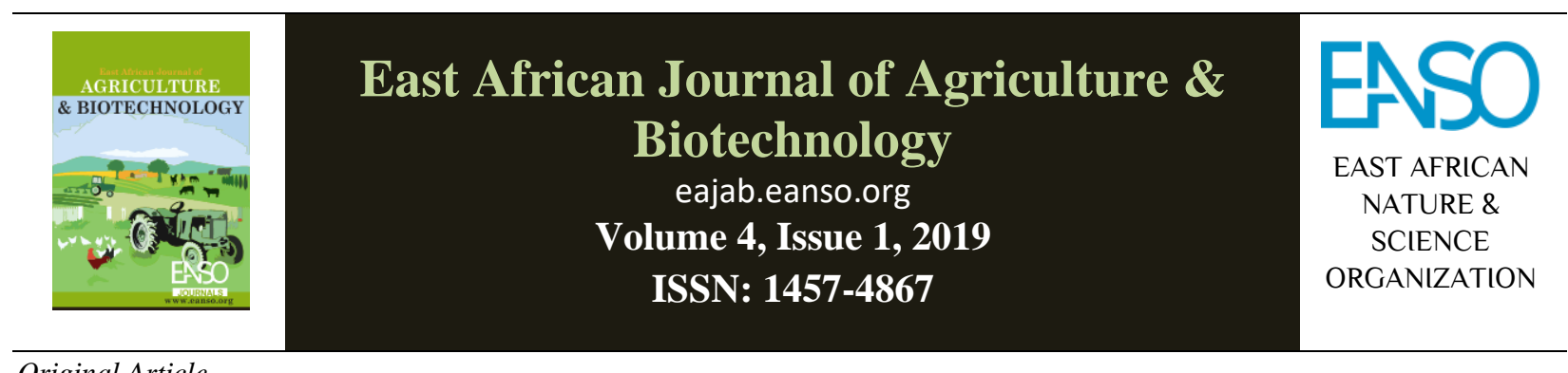

Original Article

\title{
RETROSPECTIVE STUDY OF THE BURDEN OF AVIAN INFLUENZA IN KANO STATE, NIGERIA: A SECONDARY DATA ANALYSIS 2015-2017
}

\author{
Solomon Chieloka Okoli ${ }^{1}$, Celestine Ameh ${ }^{2}$, Muhammad Shakir Balogun ${ }^{3}$, \\ Abdulkareem Durosinlorun ${ }^{4}$, Columba Vakuru ${ }^{5} \&$ Alabi Olaniran 6 \\ ${ }^{1}$ Federal Ministry of Agriculture and Rural Development, Nigeria, okoli28@gmail.com. \\ ${ }^{2}$ African Field Epidemiology and Laboratory Training Network, Nigeria, cameh@afanet.net. \\ ${ }^{3}$ African Field Epidemiology and Laboratory Training Network, Nigeria, msbalogun@afenet.ng. \\ ${ }^{4}$ Federal Ministry of Agriculture and Rural Development, Nigeria, abdul4boys@gmail.com. \\ ${ }^{5}$ Federal Ministry of Agriculture and Rural Development, Nigeria, colvakuru@yahoo.com \\ ${ }^{6}$ Federal Ministry of Agriculture and Rural Development, Nigeria, olanlabi@gmail.com.
}

DOI: https://doi.org/10.37284/eajab.1.1.40

\section{Article history:}

Received: 27 Sep 2019

Accepted: 10 Oct 2019

Published: 19 Oct 2019

Keywords:

Avian Influenza (AI), Local Government

Areas,

LGAS,

Highly Pathogenic

Avian Influenza,

HPAI,

Biosecurity

\section{ABSTRACT}

Over 1.2 million poultry birds were infected with highly pathogenic avian influenza (HPAI) (H5N1) in Nigeria between 2006 and 2008. A resurgence of HPAI in 2014 in Kano and its spread to other states plagued the poultry subsector with job losses, increased poultry mortality and a drastic fall in revenues. We carried out this study to determine the pattern, trend and burden of HPAI in poultry birds between 2015 and 2017 in Kano State Nigeria. We obtained Avian Influenza (AI) surveillance data for 2015-2017 from the Federal Ministry of Agriculture, Abuja. Variables analyzed were the number of poultry chicken affected, mortality in infected poultry, the number of poultry depopulated by local government areas (LGAs), and trends of avian influenza within the study area. In the years under review, over 3.7 million poultry chickens were affected across 26 states in Nigeria. Kano State accounted for $30 \%$ of the total mortality in Nigeria. In $2015,648,686$ poultry chickens were exposed to HPAI, H5N1 across 21 LGAs in Kano, 34,504 (5.3\%) died, 561,126 (94.7\%) was depopulated. In 2016, 382,963 poultry birds were exposed, 9,737 (2.5\%) died and 375,026 (94.7\%) poultry was depopulated. In 2017, targeted surveillance conducted on a pool of ducks at Sabon Gari market in Kano led to the isolation of HPAI. H5H8. The decline in the incidence of AI cases from week 17-31 of 2015 and week 13-33 of 2017 was in tandem with supplies of AI control kits and equipment to Kano State. These measures should be complemented with the training of poultry stakeholders on biosecurity measures 
on the farm with a view of preventing a future outbreak of avian influenza. These findings have been communicated to the Chief veterinary officer of Nigeria for consideration.

\section{INTRODUCTION}

Epidemics caused by influenza viruses account for about 3-5 million cases of severe illness and about 250,000-500,000 deaths worldwide (WHO, 2018). Viruses of the genus influenza A. cause avian influenza (AI). They are classified based on their surface proteins, Hemagglutinin (HA) and Neuraminidase (NA). Wild birds are the main reservoir of avian influenza viruses (Swayne, 2009). Avian influenza virus (H5N1) causes zoonotic infection (FDVS, 2017). Influenza A (H5N1) Zoonoses was first reported in Hong Kong in 1997, curiously none of the affected individuals worked in the poultry industry (Shortridge, 1999). Nigeria reported one suspected human fatality in Lagos Nigeria in 2006 (Monne et al., 2008). Highly pathogenic avian influenza was first reported in Nigeria in 2006 (Coker et al., 2014) and it persisted until 2008 where 25 states of the federation were affected across 97 LGAs (Pagani, Abimiku \& Emeka-Okolie, 2008), but Nigeria was declared free of AI in 2013 ( FMARD, 2003). In 2015, a resurgence of avian influenza $\mathrm{H} 5 \mathrm{~N} 1$ was reported in Nigeria following increased mortality of poultry birds at Live bird market in Lagos and backyard poultry farm in Kano State (Monne et al., 2015). In the first quarter of 2018, Kano state reported the highest-burden of avian influenza within 29 of 44 LGAs affected (FDVS \& PC, 2018). H5N1 has been isolated in all confirmed outbreak of Highly pathogenic avian influenza in poultry in Nigeria since 2006, however, a targeted surveillance carried out by the Federal department of veterinary services and the Veterinary research institute Jos on a pool of apparently healthy ducks at the live bird market (LBM) in Sabon Gari Kano on (11/01/2017) was positive for avian influenza strain H5N8. Since then, H5N8 caused an outbreak in poultry chicken in Bauchi and plateau State Nigeria in 2019 (FAO, 2019). The Federal Government of Nigeria adopted a 'No Vaccination Policy' which prohibited vaccination of poultry birds against AI.
Consequently, the affected poultry were humanely slaughtered during an outbreak poultry farms are decontaminated, disinfected and compensation paid to affected farmers. These policies aimed at reducing the burden of losses by the farmer, prevent risk of spread due to sale of infected poultry has had significant effect on stamping out avian influenza from the poultry subsector; however, these gain may be marginal largely due to the poorly regulated and unstructured poultry value chain (Pagani, Abimiku \& Emeka-Okolie, 2008). This study has brought to the fore the burden of pathogenic avian influenza on the poultry subsector in Kano State with a view to providing information necessary for action.

\section{METHODOLOGY}

Kano State is located in the Northwest of Nigeria; it was created on May 27, 1967; It has 44 LGAs (NBS, 2018). Katsina State borders Kano State to the Northwest, Jigawa State to the north-east, Bauchi State to the southeast and Kaduna State to the southwest. It has a total land area of $20,131 \mathrm{Km}^{2}$ with a population of 9.3 million based on 2006 population censors. Agriculture is the major trade of its inhabitants (NBS, 2018). Before 2006 the total poultry population in Nigeria was 140 million (Pagani, Abimiku \& Emeka-Okolie, 2008). Kano State accounted for 3.8 million about $17.7 \%$, a greater percentage of these poultry chickens are local chicken kept under extensive (traditional) husbandry management system (Adene \& Oguntade, 2006; FAO, 2018). Nigeria reported an estimated poultry population of 180 million in 2018 (FAO, 2018).

Secondary data on the resurgence of avian influenza in Nigeria from (2015-2017) was obtained from the Federal Department of Veterinary Services, Abuja. The data was cleaned and displayed on a spreadsheet. Variables analyzed were the number of poultry chicken affected, mortality in infected poultry, the number of poultry 
depopulated by (LGAs), and trends of avian influenza in Kano State. The result was presented in tables, Spot maps and figures as appropriate. This is a three years retrospective study which involves analysis of secondary data based on the resurgence Figure 1: Spot Map of Kano Showing States Showing LGAs with Confirmed Cases of Avian Influenza 2015-2017

of avian influenza in Kano state Nigeria between 2015 and 2017.

\section{RESULTS AND DISCUSSIONS}

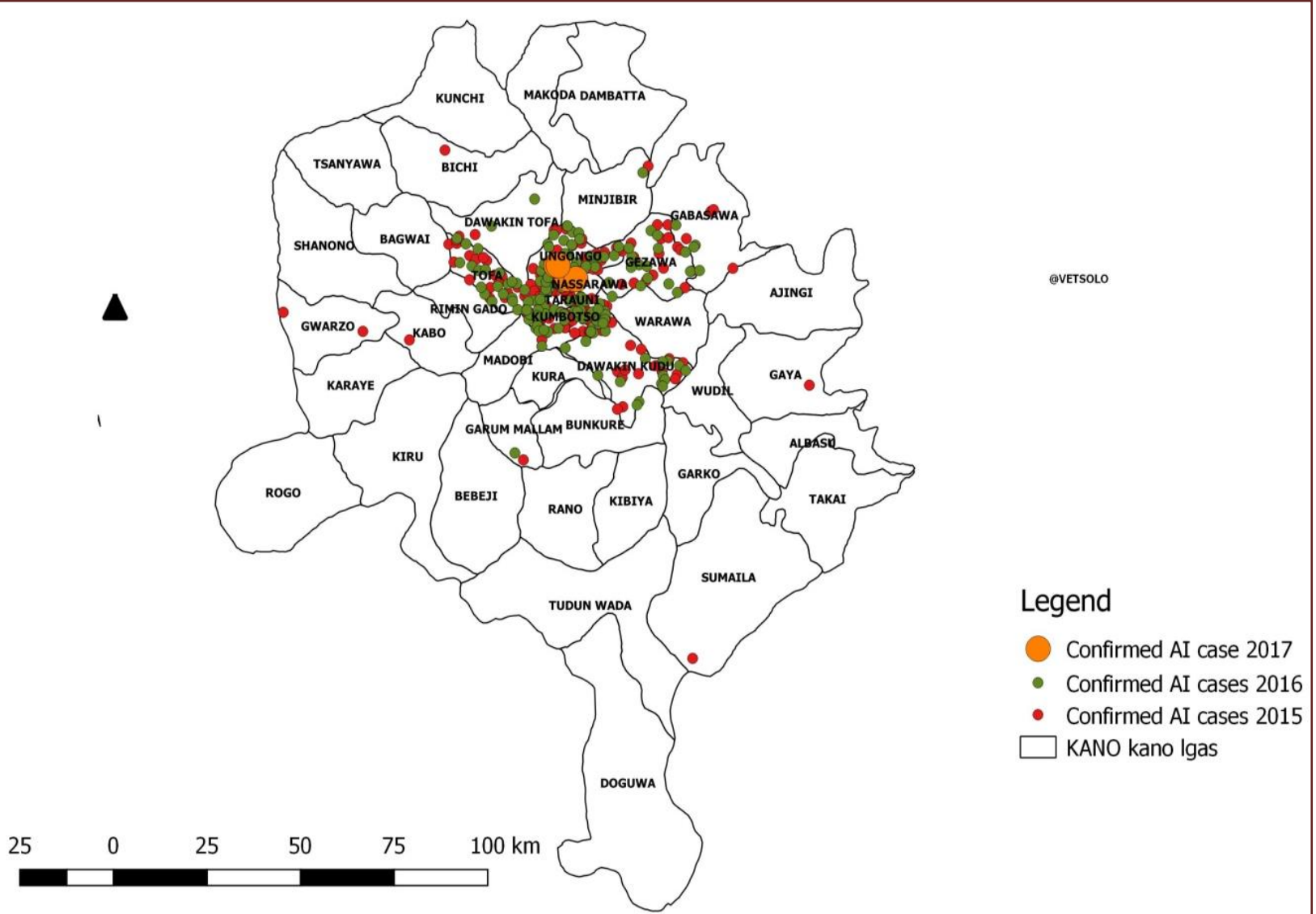

Source: (FDVS and PCS, 2018)

Kombotso LGA reported the largest confirmed cases of AI in 2015 the outbreak pattern depicts a concentric spread from Kombotso LGA to contiguous LGAs, Madobi, Minjibir, Fagge, Tofa, D/Tofa, Sumaila, Kabo, and Gaya. Road transport seemed to be the easiest mean of transport and

Table 1: Summary of the burden of avian influenza per LGAs affected in Kano State Nigeria

\begin{tabular}{lllllll}
\hline LGAs & $\begin{array}{l}\text { Confirmed } \\
\text { Cases in LGA }\end{array}$ & $\begin{array}{l}\text { Poultry } \\
\text { Exposed }\end{array}$ & Mortality & $\begin{array}{l}\text { Poultry } \\
\text { Depopulated }\end{array}$ & $\begin{array}{l}\text { Mortality } \\
\text { Rate }\end{array}$ & Summary \\
\hline Bichi & 1 & 950 & 250 & 700 & 26.3 & \\
Dala & 7 & 6,599 & 177 & 6,422 & 2.70 & \\
Dawakin Kudu & 16 & 60,639 & 1,639 & 5,900 & 2.70 & \\
\hline
\end{tabular}


East African Journal of Agriculture and Biotechnology, 4(1), 2019

\begin{tabular}{lllllll}
\hline LGAs & $\begin{array}{l}\text { Confirmed } \\
\text { Cases in LGA }\end{array}$ & $\begin{array}{l}\text { Poultry } \\
\text { Exposed }\end{array}$ & Mortality & $\begin{array}{l}\text { Poultry } \\
\text { Depopulated }\end{array}$ & $\begin{array}{l}\text { Mortality } \\
\text { Rate }\end{array}$ & Summary \\
\hline Dawakin Tofa & 2 & 53,635 & 5,640 & 47,993 & 10.50 & \\
Fagge & 1 & 470 & 75 & 395 & 16.00 & \\
Gabasawa & 4 & 119,907 & 6,782 & 113,125 & 5.70 & \\
\hline Garum/M & 1 & 23 & 23 & 23 & 100.00 & HIGHEST \\
Gaya & 1 & 6,500 & 700 & 5,800 & 10.80 & \\
Gezawa & 16 & 39,281 & 1,568 & 37,713 & 4.00 & \\
Gwale & 17 & 32,134 & 3,786 & 28,348 & 11.80 & \\
Gwarzo & 2 & 1,200 & 400 & 800 & 33.30 & \\
Kabo & 1 & 4,500 & 262 & 4,238 & 5.80 & \\
K/Municipal & 4 & 185 & 23 & 162 & 12.40 & \\
\hline Kumbotso & 45 & 206,772 & 2,240 & 204,532 & 1.10 & LOWEST \\
Madobi & 1 & 142 & 15 & 127 & 10.60 & \\
Minjibir & 1 & 12,057 & 2,249 & 9,808 & 18.70 & \\
Nasarawa & 14 & 7,817 & 565 & 7,252 & 7.20 & \\
Sumaila & 1 & 700 & 84 & 616 & 12.00 & \\
Tarauni & 6 & 3,805 & 275 & 3,530 & 7.20 & \\
Tofa & 20 & 51,764 & 3,962 & 47,802 & 7.30 & \\
Ungogo & 26 & 39,629 & 3,789 & 35,840 & 9.60 & \\
\hline LGA 21 & $\mathbf{1 8 6}$ & $\mathbf{6 4 8 , 7 0 9}$ & $\mathbf{3 4 , 5 0 4}$ & $\mathbf{5 6 1 , 1 2 6}$ & & \\
\hline
\end{tabular}

Percentage of the number of birds that died due to exposure to AI was determined by: $\frac{\text { Mortality }}{\text { Total exposed poultry }} \times 100 \%$ which was $5.3 \%$ while the percentage of the number of birds that were humanely slaughtered were determined $\frac{\text { No. of bird depopulated }}{\text { Total no. of exposed birds }} \times 100 \%$. It was noted that $8.1 \%$ of the exposed bird has no data to support its depopulation.

Figure 2: Trend of suspected and confirmed cases of avian influenza across affected LGAs of Kano Jan -Dec 2015

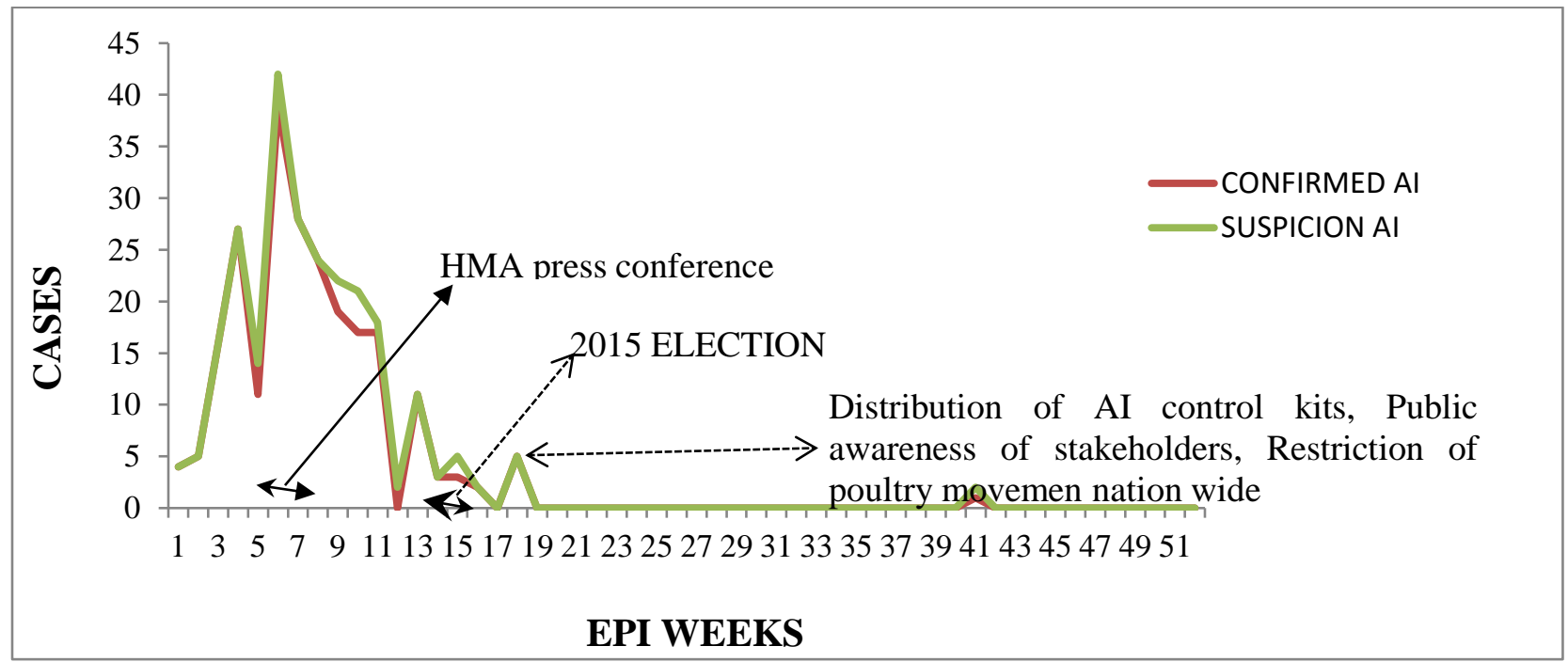


East African Journal of Agriculture and Biotechnology, 4(1), 2019

There was a gradual rise in the number of AI cases from week 1 to 3 , which culminated into 5 cases in week $3-4$, this was followed by a spike to 15 cases by week 4 however by week 5-7 which correspond with the press conference held by the Honorable Minister of Agriculture [HMA] to sensitize poultry stakeholders on the re-emerging zoonoses of avian influenza. Consequently, after week 7 there was an increase in the number of cases with a spike as high as 42 cases, this rise in confirmed cases may be attributed to the increase in awareness of the poultry stakeholders on avian influenza following the Minister's press conference. However, from week $8-12$, there was a gradual decline in cases with a deep in the number of cases in week 13. Week 1415 witnessed a further decrease in the number of confirmed cases from 10-14; there was a further reduction in the number of cases by week 16 which correspond to the Nigerian presidential election of 2015. By week 17 through 31, the Federal Ministry of Agriculture and its partner agencies such as FAO, World Bank, and USAID commenced the distribution of AI control equipment to all the 36 states of Nigeria and Federal Capital Territory (FCT). Sensitization of the poultry stakeholders and increased restriction on the movement of poultry and poultry products. This may have accounted for the marked decrease in the number of reported cases until week 41; however, there were no reported cases after epidemiologic week 41 of 2015.

Table 2: Summary of the burden of the avian influenza outbreak in Kano state 2016

\begin{tabular}{|c|c|c|c|c|c|c|}
\hline$L G A s$ & $\begin{array}{l}\text { Confirmed Cases } \\
\text { in LGA }\end{array}$ & $\begin{array}{l}\text { Poultry } \\
\text { Exposed }\end{array}$ & Mortality & $\begin{array}{l}\text { Poultry } \\
\text { Depopulated }\end{array}$ & $\begin{array}{l}\text { Mortality } \\
\text { Rate }\end{array}$ & Summary \\
\hline Dagwai & 1 & 450 & 85 & 365 & 18.90 & Highest \\
\hline Babeji & 2 & 200,000 & 1,562 & 198,438 & 0.80 & \\
\hline Bunkure & 1 & 7,824 & 66 & 7,758 & 0.40 & \\
\hline Dala & 2 & 282 & 44 & 238 & 15.60 & \\
\hline D/Kudu & 5 & 20,185 & 465 & 19,720 & 2.30 & \\
\hline D/Tofa & 2 & 4,158 & 282 & 3,876 & 6.80 & \\
\hline Garum/M & 3 & 760 & 12 & 748 & 1.60 & \\
\hline Garko & 2 & 617 & 23 & 594 & 3.70 & \\
\hline Fagge & 1 & 2,000 & 2,000 & 2,000 & 100.00 & \\
\hline Gezawa & 4 & 10,000 & 591 & 9,409 & 6.00 & \\
\hline Gabasawa & 1 & 500 & 23 & 477 & 4.60 & \\
\hline Gwale & 11 & 4,485 & 316 & 4,169 & 7.10 & \\
\hline K/Municipal & 1 & 120 & 29 & 91 & 24.20 & \\
\hline Kumbotso & 30 & 74,458 & 2,321 & 72,137 & 3.10 & \\
\hline Kura & 3 & 9,122 & 149 & 8,973 & 1.60 & \\
\hline Madobi & 1 & 4,200 & 10 & 4,190 & 0.20 & Lowest \\
\hline Minjibir & 1 & 11,567 & 58 & 11,509 & 0.50 & \\
\hline Nasarawa & 9 & 9,491 & 481 & 9,010 & 5.10 & \\
\hline Rano & 1 & 711 & 62 & 649 & 8.70 & \\
\hline Rimin Gado & 1 & 470 & 10 & 460 & 2.10 & \\
\hline Rogo & 1 & 500 & 20 & 280 & 4.00 & \\
\hline Tarauni & 5 & 6,255 & 202 & 6,053 & 3.20 & \\
\hline Tofa & 6 & 7,500 & 269 & 7,231 & 3.60 & \\
\hline T/Wada & 1 & 2,500 & 300 & 2,200 & 12.00 & \\
\hline Ungogo & 5 & 4,808 & 357 & 4,451 & 7.40 & \\
\hline LGA 25 & 100 & 382,963 & 9,737 & 375,026 & 100.00 & \\
\hline
\end{tabular}


Total exposed bird to avian influenza per LGAs in 2016 was 382, 963; the total number of bird that died due to exposure to AI was 9,737 while the total number of birds humanely slaughtered/Depopulated was 375,026 . The percentage of the number of birds that died due to exposure was determined by $\frac{\text { Mortality }}{\text { Total exposed poultry }} x 100 \%$ which was $97.9 \%$. It was noted that Rano, Rimi, Gado, Rogo, Garko, Garum Mallam, Babeji, Bunkure, and Bagwai were the new LGAs affected by AI in 2016 epidemiological year.

Figure 3: Spot map of Kano State depicting the proportion of LGAs with confirmed cases of avian influenza from Jan-Dec 2016

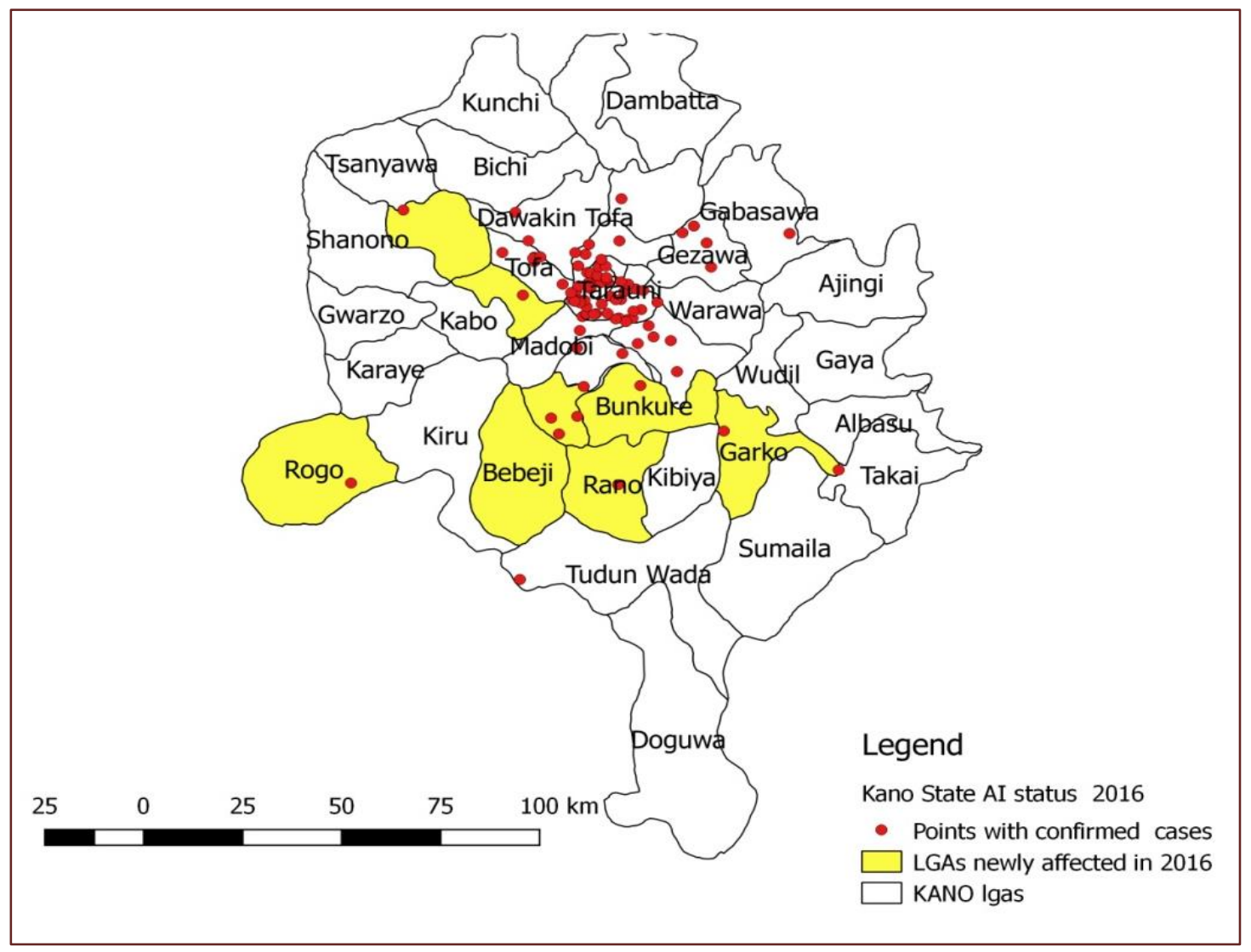

In 2016, Kumbusto LGA accounted for the highest-burden of AI, the distribution of the spread of confirmed cases is concentric; however, they appear to be a mild spread to contiguous LGAs
(Madobi, Warawa, Gezawa and Tofa) and as far as (Rogo and Gabasawa). Road transport may have contributed to spreading due to the proximity of the LGAs 
Table 4: Trend of suspected and confirmed cases of avian influenza across affected LGAs in Kano State, Jan -Dec 2016

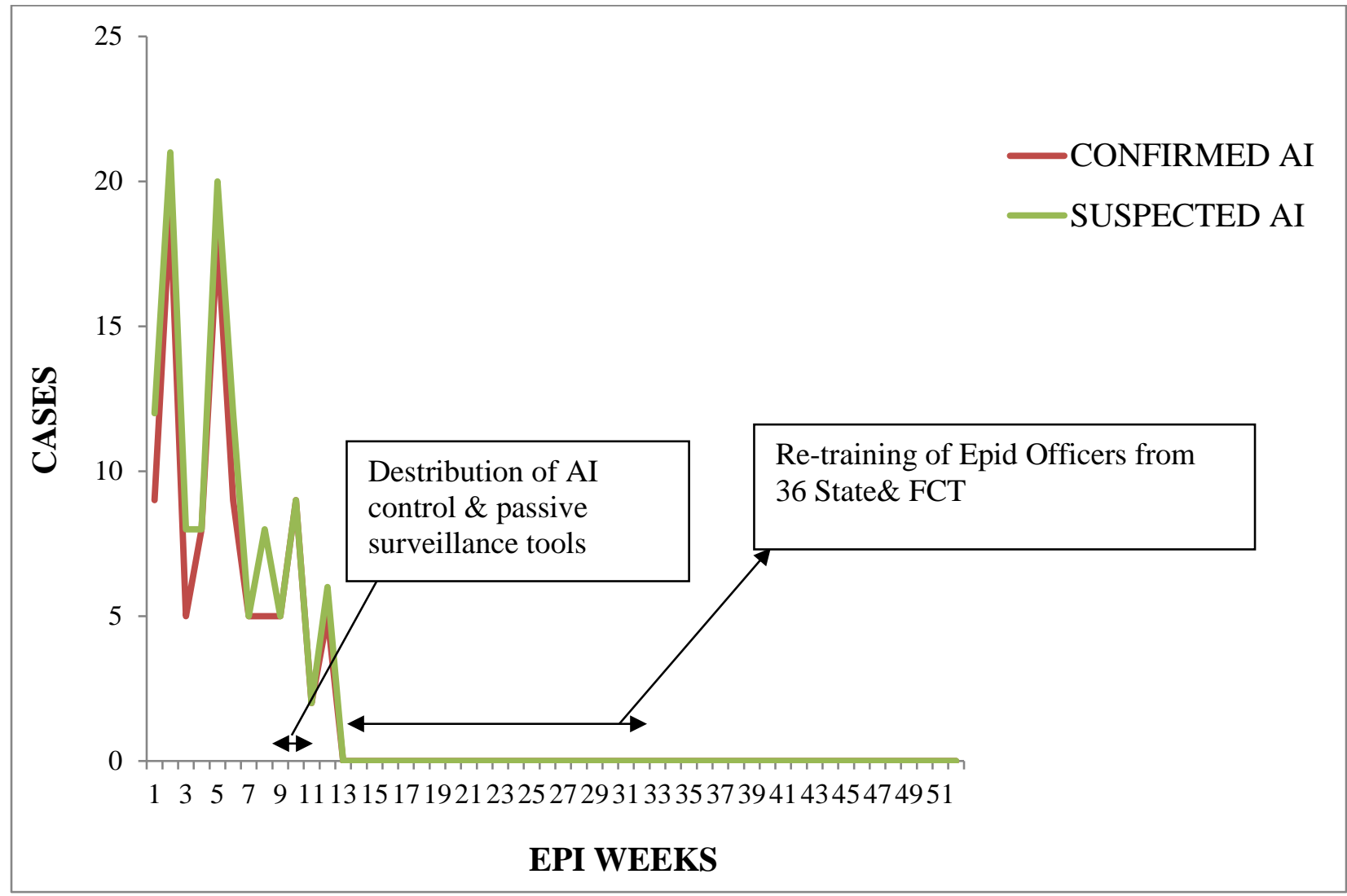

Despite the control measures instituted by the Federal Department of Veterinary services and her partner agencies which saw the drastic reduction in the number of cases from weeks 19-52 of 2015, there was an upsurge in cases between weeks 1-2 which peaked at 19 cases. This was followed by a decline to about 5 cases by week 3 . However, by week 4, 5 cases were reported; this was followed by a sharp increase to 8 cases by week 5 . Between weeks 6 and 7, there was another spike in the number of confirmed cases to 18 which culminated into a drop of 5 cases by week 8 ; cases remained constant until week 10 with 9 reported cases. By week eleven, there was a deep to 2 cases followed by a rise to cases between weeks 12-13. However, by week 13, the Federal Department of Veterinary Services (FDVS) commenced the distribution of avian influenza control equipment targeted at strengthening containment while maintaining the capacity building of epidemiology officer towards containment. This may have accounted for the drop in the number of cases from week 14-52 of 2016 epidemiological year.

Table 3: Summary of the burden of avian influenza per LGAs affected in Kano State Nigeria between Jan-Dec 2017

\begin{tabular}{|c|c|c|c|c|c|c|}
\hline LGA & $\begin{array}{l}\text { No. of } \\
\text { confirmed } \\
\text { cases }\end{array}$ & $\begin{array}{l}\text { No. of } \\
\text { exposed bird }\end{array}$ & Mortality & $\begin{array}{l}\text { No } \\
\text { depopulated }\end{array}$ & $\begin{array}{l}\text { \% } \\
\text { Mortality }\end{array}$ & Summary \\
\hline Sabon/Gari & 4 & ------ & -------- & -------- & 100 & $\begin{array}{l}\text { Targeted surveillance } \\
\text { on a pool of duck was } \\
\text { +ve for H5N8 }\end{array}$ \\
\hline
\end{tabular}


In 2017, Kano State reported only one confirmed case of avian influenza H5N8 in a pool of Ducks during targeted surveillance at Sabon Gari market. This came as a backdrop of continued active zerosurveillance undertaken by the Federal department of veterinary services since 2016 which saw to a drop in reported cases from week 14-52 of 2016. Since this discovery, the sporadic outbreak of highly pathogenic avian influenza $\mathrm{H} 5 \mathrm{~N} 8$ has been reported in poultry in Jos and Bauchi state (FAO, 2019).

Figure 5: Trend of confirmed cases of avian influenza across affected LGAs of Kano states 2015-2017

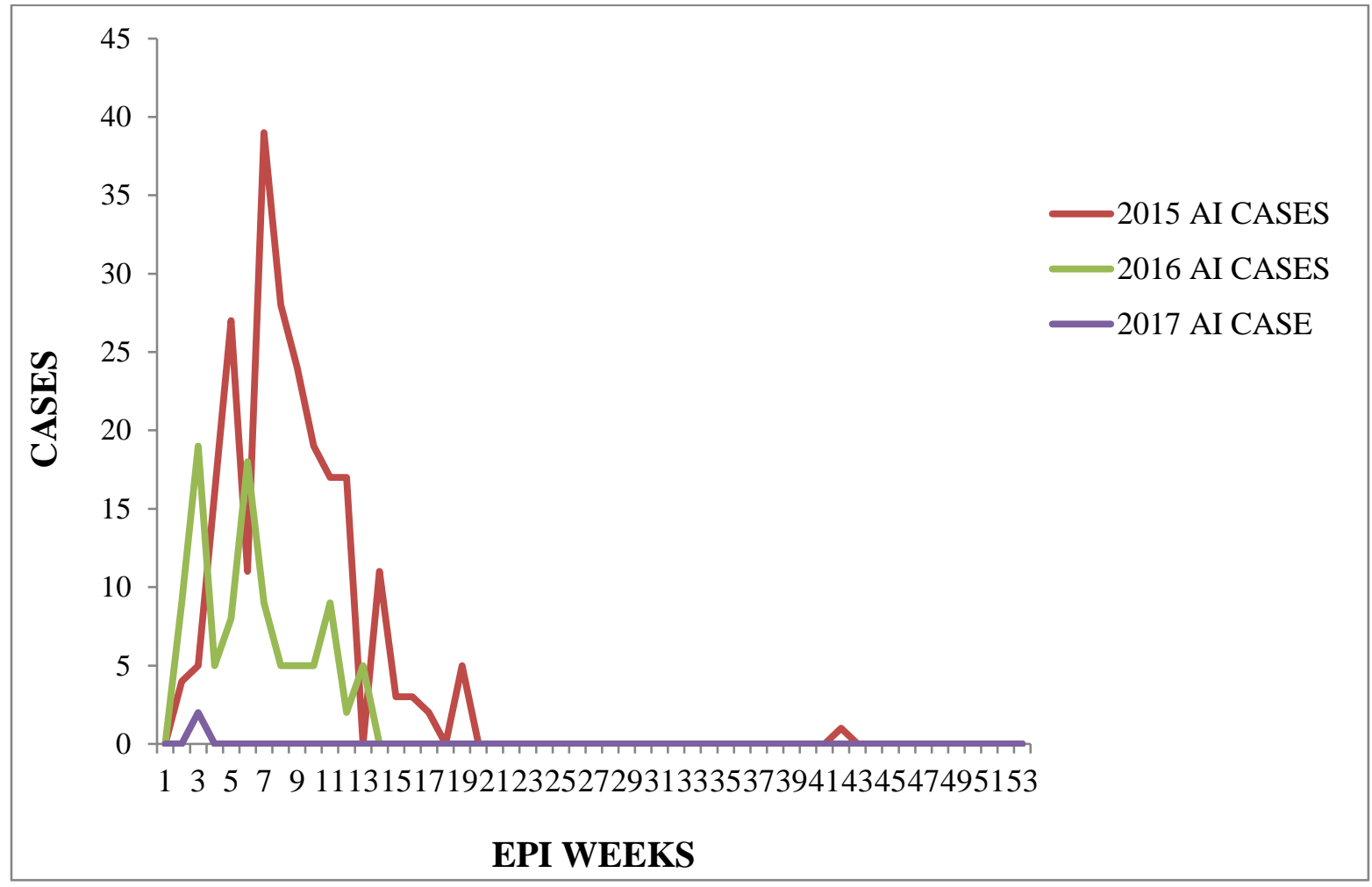

There was a marked decrease in the number of confirmed cases of avian influenza from a peak of 40 cases in 2015 to 27 cases in 2016 and 19 cases in 2017. Comparing the number of distinct peaks 2015/2016 has four distinct peaks while 2017 had on one. Similarly, 648,686 birds were exposed to AI in 2015, 34504 (5.3\%) died, and 561,126 $(94.7 \%)$ was humanely slaughtered/depopulated. In 2016, 382,963 poultry birds were exposed to AI in
Kano state 9,737 (2.5\%) died while 375,026 $(94.7 \%)$ was humanely slaughtered, however. In 2017, there was no reported mortality due to AI, effective control measures, training and retraining of epidemiologic officers by the Federal department of veterinary services may have played a large role in the reduction in the incidence of avian influenza in Kano state from 2015-2017. 
Figure 6: Adaptive changes in the epidemiology of migratory birds; the role of Tiga Dam in Kano

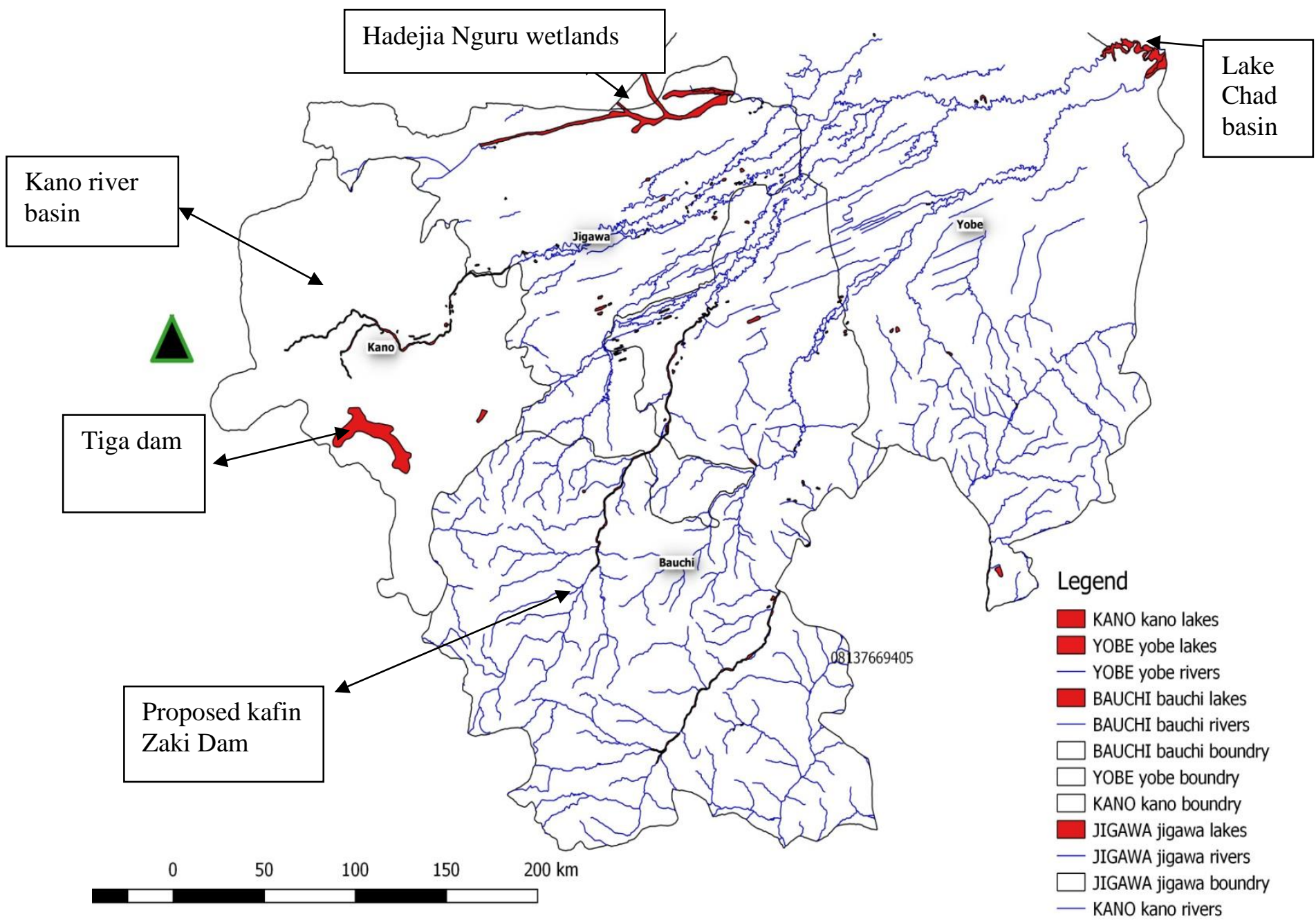

The emergence of the influenza H5N8 virus in subSaharan Africa between 2016-2017 has raised concerns regarding its potential to become endemic and spread within the sub-region (FAO, 2017). The Tiga Dam constructed between 1971-1974 in an attempt to ensure food security in the region (Shettima, 1997) may play a major in the epidemiology of avian influenza. The Kano river is the main tributary of Hadejia river with Jama are' river supplies the Yobe river and Hadejia-Nguru wetland with an estimated population of migratory waterbirds between 200,000-325,000, which roast and breed in this region (Shettima, 1997). Studies have also shown a fall of 100 million cubic meters of water per year downstream at Gashua in Yobe
State since the completion of the Tiga dam (the Federal Republic of Nigeria, 2017).

Consequently, reduced water inflow downstream due to the closure of the Tiga Dam during farming seasons may influence upstream migration of water birds toward flood plains and Irrigated wetlands to breed and winter. This change in the ecology of the environment may increase the chance of contact of migratory birds with indigenous poultry flock. Similarly, such migratory bird may be captured during hunting season and sold at the live bird market where there is a high risk of mixing of these carriers or reservoirs birds with other indigenous poultry species, thus the introduction of a new strain of influenza virus into naïve population. 
Similarly, the proposed construction of Kafin Zaki Dam along the Jama'are' river in Bauchi State (Shettima, 1997), a major tributary of Yobe river and Hadejia-Nguru wetland may further lead to a reduction in the volume water supplied to the wetland. Therefore, the increased movement of migratory bird upstream toward irrigated wetland, where they risk being captured by hunters and transmission of infection to local poultries in that region. Reduced water inflow downstream due to the closure of the Tiga Dam during farming seasons may have influenced the upstream migration of water birds toward flood plains and irrigated wetlands to breed and in winter made contact with local bird, This increased the risk of being captured by hunters who sell them to local poultry marketers at the live bird market where there is a high risk of mixing of local chicken with migratory wild bird who may be reservoirs of avian influenza (Pagani, Abimiku \& Emeka-Okolie, 2008).

A resurgence of avian influenza $\mathrm{H} 5 \mathrm{~N} 1$ was reported in Nigeria in 2015, following increased mortality of poultry bird kept at a backyard farm in Kano. As at the last quarter of 2017, over 3.2 million birds had been exposed to avian influenza in Nigeria, Kano state accounted for $30 \%$ of these statistics. In 2015, 648,686 birds were exposed to avian influenza in Kano state, 34,504 (5.3\%) died while 561,126 (94.7\%) was depopulated. In 2016, 382,963 poultry birds were exposed to avian influenza, 9,737 (2.5\%) died due to this exposure while $375,026(94.7 \%)$ was humanely slaughtered; however, in 2017 there was no reported mortality due to avian influenza in Kano State. In all between 2015- 2017, 25 LGAs was affected across 44 LGAs of Kano state, Kombutso LGA accounted for the highest-burden of avian influenza during this period. Analysis of the distribution infection across the affected LGAs appears to be concentric from with disease spread from Kombutso LGA to other contiguous LGAs. Similarly, land transport seems more plausible in these spreads due to the proximity of affected LGAs. Targeted surveillance conducted by the Federal Department of Veterinary Services and the National Veterinary Research Institute Jos on a pool of ducks at Sabon Gari market Kano led to the isolation of H5H8 (FDVS \& PC, 2018).

The growth of the poultry subsector has been stunted by diseases (FAO, 2018). Mixed farming and rearing multiple species of poultry in backyard farm are risk factors (Smith \& Dunipace, 2011). Backyard poultry is an important sentinel in the maintenance of influenza viruses (Fasina et al., 2011). Fasina, Sirdar and Bisschop (2008) posited that there was a high odd of disease outbreak in poultry farms with flocks from an infected farm. The direct cost and losses due to the 2006-2008 outbreak of avian influenza in Nigeria were estimated at $\$ 617$ million (Fasina, Sirdar \& Bisschop, 2008), this contrast with over $\$ 3$ billion already paid in compensation to affected farmers as at the third quarter of 2017 following avian influenza resurgence in 2015 (FDVS \& PC, 2018). Avian influenza outbreaks in Kano State were clustered around Kumbusto LGA with a characteristic concentric spread to contiguous LGAs (Madobi, Minjibir, Fagge, Tofa, and Dawakin Tofa) between 2015-2017. Restriction on movement of poultry and poultry product played a major role in the decline in confirmed cases from 45 to 30 cases in 2016, which was in tandem with (Monne et al., 2008). Depopulation, disinfection, and compensation of affected farmer remain an effective strategy in control of avian influenza in Nigeria was concerned that avian influenza might not be eradicated in the first quarter of 2017. Targeted surveillance was conducted on a pool of ducks at the 'Sabon Gari' market lead to the isolation of avian influenza H5N8 (FDVS, 2017). This finding may have given credence to assertions by (Blench, 2004) that increasing interaction of indigenous species of poultry with overwintering Palearctic anatids may play major role in the introduction of avian influenza H5N8 into the poultry subsector.

\section{CONCLUSIONS}

The decline in the number of cases reported between weeks 17-31 of 2015 and week 13-33 of 2017 due to improved capacity of States to respond to the outbreak of avian influenza through the supply of avian influenza control equipment. Farmers in Kano State most especially, Kumbusto LGAs should be encouraged to form a cooperative society to engage the services of a Veterinarian and veterinary paraprofessionals in poultry management. These measures complement with training and retraining of poultry stakeholders on the maintenance of high biosecurity standard on the 
farms may prevent a future outbreak of avian influenza within the poultry subsector.

\section{REFERENCE}

Adene, D. F., \& Oguntade, A. E. (2006). The structure and importance of the commercial and village-based poultry industry in Nigeria. Rome, Italy: FAO, 1-109.

Blench, R. (2004). Natural resource conflicts in north-central Nigeria: A Handbook and Case Studies. London: Mandaras.

Coker, T., Meseko, C., Odaibo, G., \& Olaleye, D. (2014). Circulation of the low pathogenic avian influenza subtype $\mathrm{H} 5 \mathrm{~N} 2$ virus in ducks at a live bird market in Ibadan, Nigeria. Infectious diseases of poverty, 3(1), 38.

FAO (2018). Livestock and livelihoods spotlight Nigeria: Cattle and poultry sectors. Food and Agriculture Organization of the United Nations; Available from http://www.fao.org/3/CA2149EN/ca2149en.pd $\mathrm{f}$

FAO. (2017). H5N8 HPAI in Uganda. Food and Agriculture Organization of the United Nations. Available from:

http://www.fao.org/3/a-i7105e.pdf

FAO. (2019, Sept 11). Outbreak of Highly Pathogenic Avian Influenza in poultry. Retrieved from Food and Agriculture Organization, available at:

http://www.fao.org/ag/againfo/programmes/en /empres/HPAI_Africa/situation_update.html.

Fasina, F. O., Rivas, A. L., Bisschop, S. P., Stegeman, A. J., \& Hernandez, J. A. (2011). Identification of risk factors associated with highly pathogenic avian influenza $\mathrm{H} 5 \mathrm{~N} 1$ virus infection in poultry farms, in Nigeria during the epidemic of 2006-2007. Preventive veterinary medicine, 98(2-3), 204-208.

Fasina, F. O., Sirdar, M. M., \& Bisschop, S. P. R. (2008). The financial cost implications of the highly pathogenic notifiable avian influenza H5N1 in Nigeria. Onderstepoort Journal of Veterinary Research, 75(1), 39-46.
FDVS \& PC (2018). Avian Influenza Resurgence In Nigeria: Proportion of affected LGA per State. Federal Department of Veterinary Services.

Federal FDVS (2017). Avian Influenza Resurgence in Nigeria Daily Update Report - 16th November. Federal Department of Veterinary Services.

Federal Republic of Nigeria. (2017). Resettlement Action Plan for Kano River Irrigation Scheme in Kano State, Nigeria (SFG3496 V2). Abuja, Nigeria: Federal Republic of Nigeria. Available at:

http://documents.worldbank.org/curated/en/29 4751499934041116/pdf/SFG3496-V2-RPP123112-PUBLIC-Disclosed-7-13-2017.pdf

FMARD. (2003). Self-declaration from Nigeria on its disease-free status from notifiable avian influenza Self-declaration (p. 56-7). Abuja, Nigeria: Federal Ministry of Agriculture and Rural Development Abuja.

Monne, I., Joannis, T. M., Fusaro, A., De Benedictis, P., Lombin, L. H., Ularamu, H., ... \& Capua, I. (2008). Reassortant avian influenza virus (H5N1) in poultry, Nigeria, 2007. Emerging infectious diseases, 14(4), 637-40.

Monne, I., Meseko, C., Joannis, T., Shittu, I., Ahmed, M., Tassoni, L., ... \& Cattoli, G. (2015). Highly pathogenic avian influenza A (H5N1) virus in poultry, Nigeria, 2015. Emerging infectious diseases, 21(7), 1275.

NBS (2018). Chapter 1: Population Projection. National Bureau of Statistics, Nigeria

Pagani, P., Abimiku, Y., \& Emeka-Okolie, W. (2008). Assessment of the Nigerian poultry market chain to improve biosecurity. FAO (Nigeria, Consultative Mission on Poultry) Study, 1-65.

Shettima, K. A. (1997). Dam Politics in Northern Nigeria: The Case of the Kafin Zaki Dam. Refuge: Canada's Journal on Refugees, 16(3), 18-22.

Shortridge, K. F. (1999). Poultry and the influenza H5N1 outbreak in Hong Kong, 1997: abridged 
East African Journal of Agriculture and Biotechnology, 4(1), 2019

chronology and virus isolation. Vaccine, (17), S26-S29.

Smith, G., \& Dunipace, S. (2011). How backyard poultry flocks influence the effort required to curtail avian influenza epidemics in commercial poultry flocks. Epidemics, 3(2), 71-75.

Swayne, D. E. (2009). Avian influenza vaccines and therapies for poultry. Comparative immunology, microbiology and infectious diseases, 32(4), 351-363.

WHO (2018, Nov 6). Influenza (Seasonal) Ask the expert: Influenza $Q \& A$. Retrieved on August 1, 2019, from the World Health Organization. Available from: https://www.who.int/newsroom/fact-sheets/detail/influenza-(seasonal). (WHO, 2018). 